\title{
KARAKTERISTIK MORFOLOGI Ganoderma steyaertanum YANG MENYERANG KEBUN BENIH Acacia mangium DAN Acacia auriculiformis DI WONOGIRI, JAWA TENGAH
}

Morphological characteristics of Ganoderma steyaertanum which attacks seed orchad of Acacia mangium and Acacia auriculiformis at Wonogiri, Central Java

\author{
Nur Hidayati dan Siti Husna Nurrohmah \\ Balai Besar Penelitian Bioteknologi dan Pemuliaan Tanaman Hutan, \\ Jl. Palagan Tentara Pelajar km 15 Purwobinangun, Pakem, Sleman, Yogyakarta, Indonesia \\ e-mail: inunghidayati@yahoo.com
}

Tanggal diterima : 18 Juni 2015, Tanggal direvisi : 30 Juni 2015, Disetujui terbit : 15 September 2015

\begin{abstract}
Acacia mangium and Acacia auriculiformis seed orchards on the island of Java are associated with a different species of Ganoderma. The importance of G. steyaertanum as a pathogen of forest trees has not been previously highlighted. The aim of this study is to look at the characteristics of the G. steyaertanum which attacks two Acacia seed orchads at Wonogiri Central Java. Activities undertaken are to identify the signs of the G. steyaertanum both in the field and in the laboratory. Characterization of fungi is conventionally done by observing the morphology of signs, such as the shape and color of the fruit body, shape and color of mycelium. Morphological characteristic applied in this study has proved to be effective to identify the pathogen. G. steyaertanum was isolated from fruitbodies of affected trees and pathogenicity tests confirmed Koch's postulates. Somatic incompatibility tests demonstrated high genetic variability of the pathogen.
\end{abstract}

Keywords: $\quad$ morphology, Ganoderma steyaertanum, Acacia mangium, Acacia auriculiformis

\begin{abstract}
ABSTRAK
Kebun benih Acacia mangium dan Acacia auriculiformis di Wonogiri, Jawa Tengah terserang penyakit busuk akar yang disebabkan oleh Ganoderma steyaertanum, species yang berbeda dengan Ganoderma philipii. Tujuan penelitian ini adalah untuk melihat karakteristik G. steyaertanum yang menyerang dua kebun benih Akasia di Wonogiri Jawa Tengah. Kegiatan yang dilakukan adalah mengidentifikasi tanda-tanda $G$. steyaertanum baik di lapangan maupun di laboratorium. Karakterisasi jamur secara konvensional dilakukan dengan mengamati morfologi tanda-tanda, seperti bentuk dan warna tubuh buah, bentuk dan warna miselium serta morfologi isolat G. steyaertanum. Karakteristik morfologi yang digunakan dalam penelitian ini telah efektif untuk mengidentifikasi patogen. G. steyaertanum yang diisolasi dari badan buah tanaman akasia yang terinfeksi penyakit busuk akar. Pengujian patogenesitas telah dikonfirmasi dengan Postulat Koch. Tes uji somatik inkompatibilitas menunjukkan variabilitas genetik yang tinggi.
\end{abstract}

Kata kunci: morfologi, Ganoderma steyaertanum, Acacia mangium, Acacia auriculiformis

\section{PENDAHULUAN}

Penyakit busuk akar merupakan penyakit yang merugikan meskipun berada dalam keadaan endemik. Ganoderma sp. menginfeksi pada jaringan akar tanaman yang kemudian tumbuh dan berkembang di bawah permukaan tanah. Gejala serangan penyakit busuk akar tingkat ringan pada tanaman secara umum adalah layu, tidak berkembang, kehilangan helai daun sampai lodoh pada batang. Pada serangan tingkat lanjut, secara umum penyakit dapat diidentifikasi dengan kemunculan tubuh 
buah. Tubuh buah ini keras dan berkayu dengan ukuran yang cukup besar. Ukuran tubuh buah dapat mencapai diameter $15 \mathrm{~cm}$ dan ketebalan $5 \mathrm{~cm}$. Warna tubuh buah dari cokelat muda hingga cokelat tua dan bahkan jingga. Bagian atas tubuh buah dapat agak mengkilat dengan bagian bawah berwarna putih (Henessy dan Daly, 2007). Tanda tanaman yang terserang tampak pada akar yang terinfeksi yaitu adanya miselium berwarna krem yang selanjutnya berubah menjadi merah sampai kehitaman. Miselium berwarna putih ditemukan pada bagian dalam akar yang terinfeksi dan mempunyai bau yang spesifik (Mohammed, 2006). Serangan Miselium ini akan meluas membentuk selaput-selaput tebal berwarna merah (rhizomorf) yang akan tampak jelas jika dibasahi air (Aciar, 2008).

Dua kebun benih di Wonogiri, Jawa Tengah yang ditanami dengan species Akasia yang berbeda yaitu Acacia mangium (mangium) dan Acacia auriculiformis (auri) mengalami serangan busuk akar yang disebabkan oleh $G$. steyaertanum (Glen et al., 2009). Dari 69 kematian $(6,8 \%)$ tanaman mangium pada tahun 2003 yang disebabkan oleh penyakit busuk akar di kebun benih tersebut meningkat menjadi 402 kematian tanaman (40\%) pada bulan Januari 2013 (Hidayati, 2013). Tulisan ini memaparkan tentang karakteristik jamur G. steyaertanum penyebab penyakit busuk akar pada tanaman mangium dan auri yang menyerang $\mathrm{KB}$ mangium dan $\mathrm{KB}$ auri generasi pertama di Wonogiri, Jawa Tengah.

\section{BAHAN DAN METODE}

Penelitian ini menggunakan beberapa metode dalam pengamatan morfologi G.steyaertanum yaitu secara makroskopis dan mikroskopis, uji somatik inkompatibilitas dilakukan dengan metode Adaskaveg dan Gilbertson (1987) dalam Latiffah dan Ho (2005) yang telah dimodifikasi serta uji patogenesitas dengan inokulasi jamur G. steyaertanum dilakukan dengan metode Widyastuti, et al. (1998) yang telah dimodifikasi.

\section{A. Badan buah dan isolat jamur G. steyaertanum}

Jamur penyebab penyakit ini adalah jamur dari kelas Basidiomycetes yaitu $G$. steyaeryanum. Karakterisasi jamur secara konvensional dilakukan dengan mengamati tanda-tanda morfologi, seperti bentuk dan warna tubuh buah, bentuk dan warna miselium dan morfologi isolat $G$. steyaertanum, yang menyerang tanaman mangium dan auri.

Isolat jamur $G$. steyaertanum berasal dari isolasi badan buah jamur yang di ambil dari kebun benih mangium dan auri generasi pertama, Wonogiri, Jawa Tengah. Isolat ditumbuhkan pada media 
PDA (Potato Dekstrose Agar) dengan konsen-trasi 23,4 gr/600ml.

\section{B. Pengujian somatik inkompatibilitas G. Steyaertanum}

Pengujian somatik inkompatibilitas dilakukan untuk mengetahui model persebaran jamur Ganoderma dalam suatu lokasi, selain itu dapat juga digunakan untuk mengetahui keragaman genetik dari satu jenis jamur Ganoderma. Pengujian somatik inkompatibilitas dilakukan dengan memasangkan dua isolat jamur Ganoderma dipasangkan pada media PDA dalam cawan petri (berdiamater $9 \mathrm{~cm}$ ). Blok inokulum diambil dari initial plate dengan ukuran \pm 3 $\mathrm{mm}^{2}$, diletakkan dengan jarak $\pm 1-2 \mathrm{~mm}$ antar dua isolat. Pembuatan blok inokulum diusahakan mempunyai ukuran yang sama antara yang satu dengan yang lainnya dalam setiap cawan petri, agar mempunyai pertumbuhan yang seragam. Isolat induk (parents culture) dibuat dari initial plate untuk setiap isolat yang akan diuji, tujuannya sebagai referensi isolat dalam memberi skor uji pasangan. Masing-masing kombinasi isolat yang diuji dan isolat induk dibuat dalam 3 ulangan. Kultur jamur diinkubasi pada suhu $25^{\circ} \mathrm{C}$ dalam ruang inkubasi. Hasil uji pasangan dievaluasi setelah 5 hari ditanam dengan menilai reaksi inkompatibilitas antar isolat berdasarkan tingkat pertentangannya dengan menggunakan metode Adaskaveg dan Gilbertson (1987) dalam Latiffah dan Ho (2005) yang telah dimodifikasi.

\section{Uji Patogenisitas G. Steyaertanum pada bibit mangium dan auri}

Uji inokulasi dilakukan untuk mengetahui patogenisitas G. steyaertanum pada tanaman mangium dan auri. Tanah digali sampai ditemukan akar tanaman akasia, kemudian akar dilukai menggunakan pisau agar menjadi jalan atau tempat masuknya jamur. Pada akar yang dilukai ditempelkan inokulum yang berupa ranting/cabang yang telah ditumbuhi koloni spora jamur G. steyaertanum sebanyak 3 buah, kemudian ditutup dengan tanah kembali. Selanjutnya dilakukan pengamatan hasil inokulasi dilakukan seminggu sekali selama 2 bulan, diamati gejala dan tanda penyakit yang muncul pada tanaman yang diinokulasi.

\section{Teknik analisis data}

Data yang diperoleh berupa data deskriptif dan dianalisis secara deskriptif.

\section{HASIL DAN PEMBAHASAN}

\section{A. Gejala dan tanda di lapangan}

Secara umum tanaman akasia yang terserang penyakit busuk akar menunjukkan gejala daun-daun menguning, layu, mengering kemudian rontok sehingga akan tampak berupa batang tanaman yang masih berdiri tegak tanpa daun-daun (Gambar 1). G. steyaertanum termasuk dalam kelas 
basidiomycetes (Alexopoulus dan Mims, 1979) yang mempunyai kemampuan mendekomposisi lignin, selulose dan polisakarida (Seo dan Kirk, 2000). Jamur ini menyebabkan akar tanaman menjadi busuk basah, lunak dan akan mengeluarkan air jika ditekan (Steinman, 1925 dalam Semangun, 2000). Hal inilah yang menyebabkan terganggunya sistem penyerapan air dan hara anorganik dari dalam tanah.

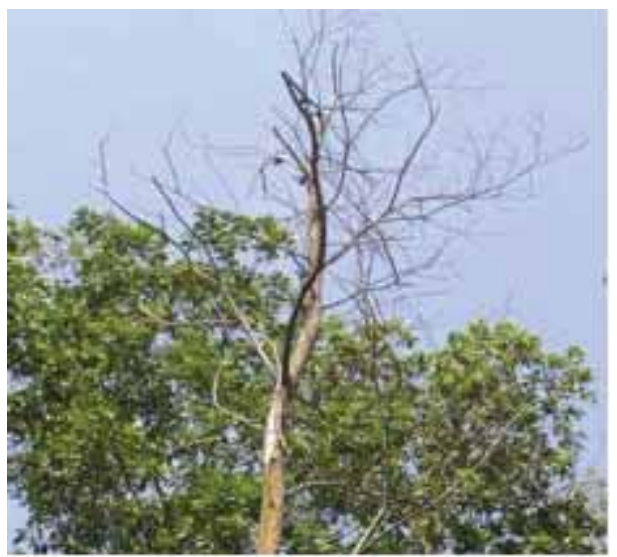

Gambar 1. Tanaman akasia yang mati karena $G$. steyaertanum.

Hasil pengamatan G. steyaertanum pada kedua tanaman akasia yaitu mangium dan auri menunjukkan ciri-ciri sebagai berikut :

1. Pada jamur yang masih muda berbentuk agak bulat dan berwarna putih, bertekstur halus jika terjadi kontak akan bercak menjadi berwarna kuning atau coklat. Pada pangkal jamur yang masih muda ini berwarna kelabu atau coklat yang semakin lama berubah menjadi hitam kecoklatan (Gambar 2.)

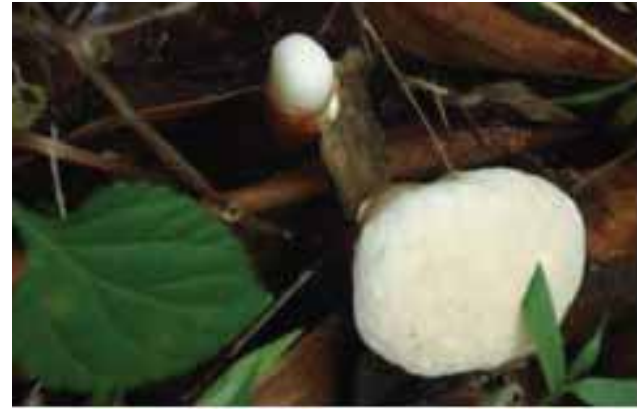

Gambar 2. Badan buah G. steyaertanum pada tingkat awal

2. Pada tubuh buah dewasa mempunyai lapisan atas yang agak licin dan tampak mengkilat berwarna coklat tua sampai coklat kehitaman, mempunyai zone-zone yang terpotong oleh lekuk atau lipatan. Zone terluar dari tubuh buah berwarna coklat dan bagian tepinya berwarna putih agak berbulu dan agak membengkak (Gambar 3a.). Berbeda dengan $G$. philipii yang mempunyai phileus badan buah yang cenderung rata, tidak bergelombang dan tidak kasar, sedangkan pada bagian permukaannya mempunyai karakteristik konsentris yang jelas dan tidak bergelombang (Aciar, 2008) (Gambar 3b).

3. Pada waktu masih baru permukaan tubuh buah yang sebelah bawah, yaitu permukaan yang berpori, berwarna putih. Ketika sudah mengering warna berubah menjadi kelabu yang kalau sudah kering sama sekali menjadi putih kotor (Gambar 4). 
4. Bila buah dewasa baru dipotong, tampak jaringan badan buah berwarna coklat merah kehitaman dan berair. Spora berukuran sangat kecil berbentuk jorong memanjang dengan pangkal yang runcing. Pada waktu masih muda tidak berwarna.
Pada akhirnya nanti ujung spora terpancung, mempunyai dinding dalam coklat kekuningan dan mempunyai tonjolan-tonjolan. Sifat ini merupakan sifat khas marga Ganoderma.
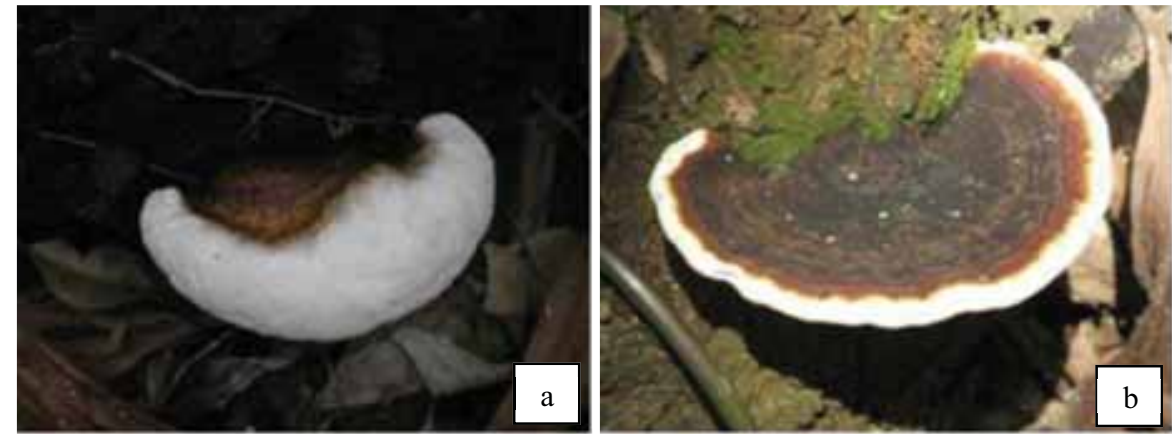

Gambar 3. Badan buah G. steyaertanum (3a) dan G. philipii (3b) tingkat dewasa
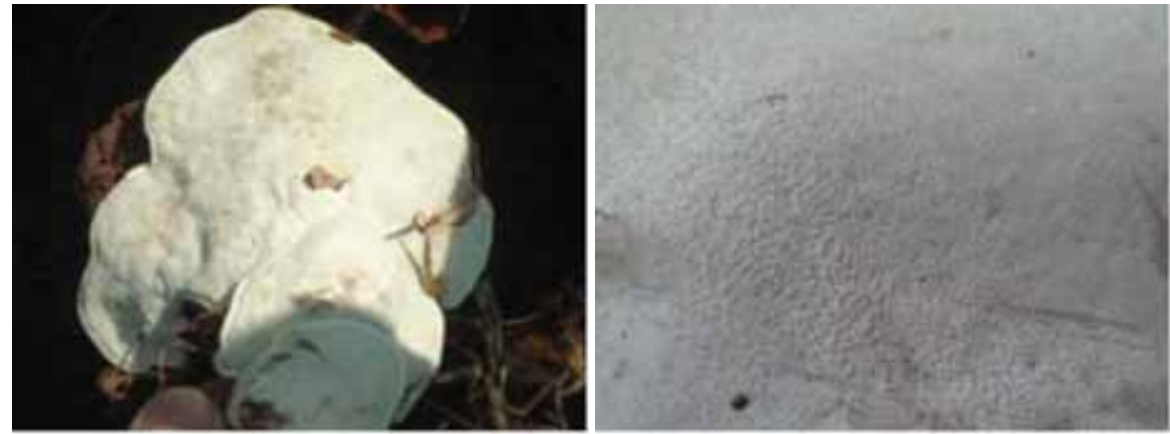

Gambar 4. Badan buah G. steyaertanum permukaan bawah

5. Dalam kondisi kering lapisan pori mempunyai warna sama dengan jaringan tubuh buah, pada waktu masih baru warnanya lebih tua dan gelap. Jaringan tubuh buah terdiri atas benang-benang jamur yang berwarna coklat (Gambar 5)

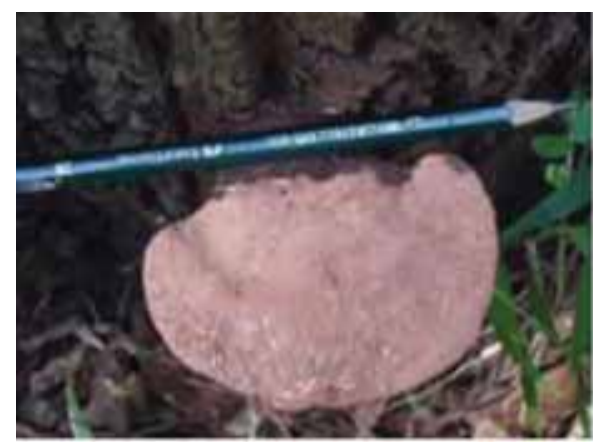

Gambar 5. Badan buah G. steyaertanum pada tanaman mangium tingkat lanjut

Pada saat akar tanaman akasia yang sakit digali, pada permukaan akar akan 
nampak benang-benang jamur (miselium) berwarna putih (Gambar 6).

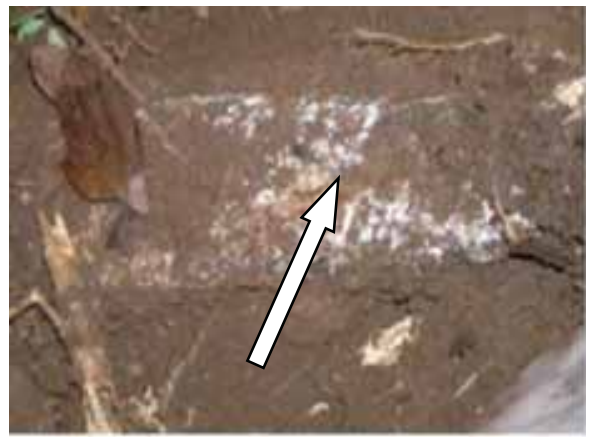

Gambar 6. Akar akasia yang terserang

G. steyaertanum, tampak miselium berwarna putih

Pada tanaman akasia yang terserang berwarna putih atau rhizomorf berwarna putih dan pada perkembangan selanjutnya rhizomorf akan berubah menjadi merah tua (Gambar 7). Warna merah ini akan tampak jelas jika permukaan akar dibasahi dengan air. Berbeda dengan akasia yang terserang G. steyaertanum, permukaan akar yang terserang busuk akar tidak tampak berwarna merah oleh rhizomorf meskipun dibasahi dengan air.

G. philipii, pada serangan awal akar tanaman akan diselimuti miselium

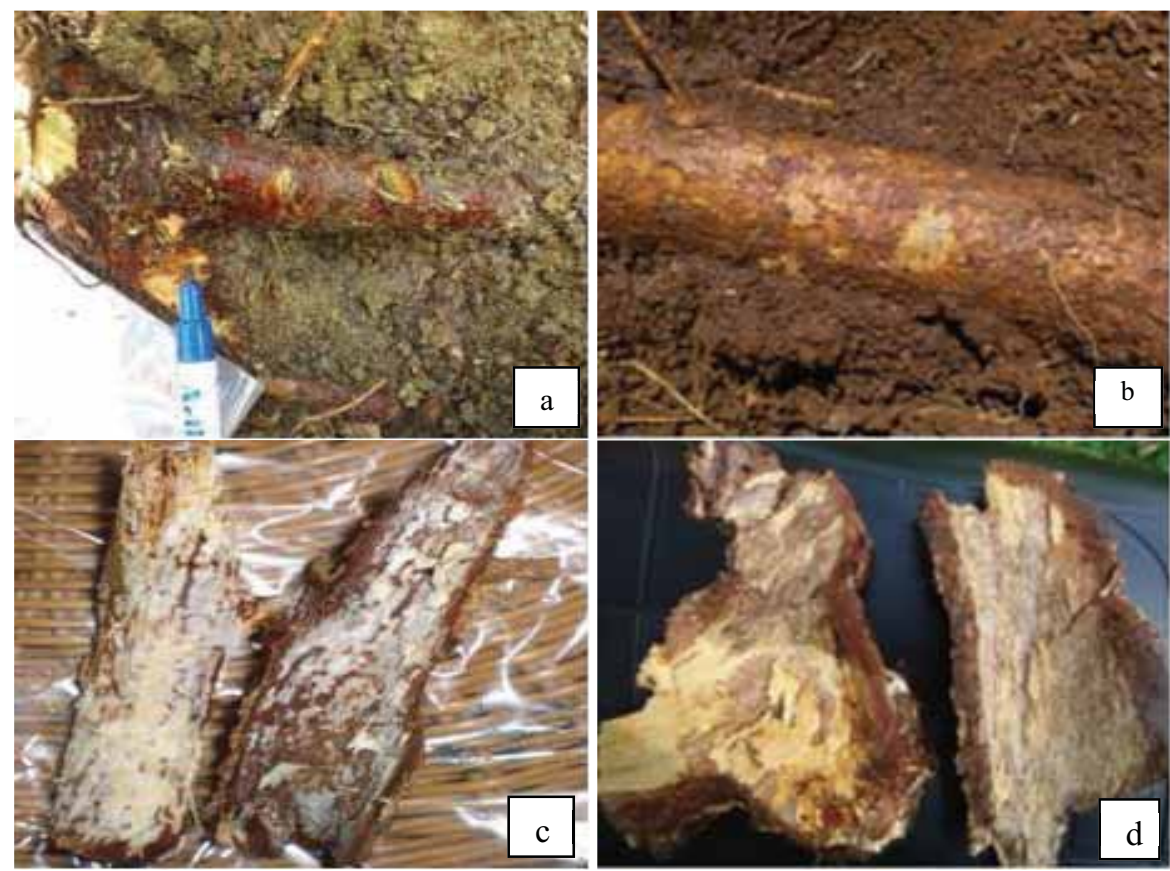

Gambar 7. Akar akasia yang terserang penyakit busuk akar
a. Akar akasia yang terinfeksi G. philipii (Doc. Aciar 2008)
b. Akar akasia yang terinfeksi G. steyaertanum
c. Akar yang terinfeksi G. philipii sebelah dalam (Doc. Aciar, 2008)
d. Akar yang terinfeksi G. steyaertanum sebelah dalam

\section{B. Uji Patogenisitas G. steyaertanum pada bibit mangium dan auri}

Uji patogenesitas di lakukan pada bibit mangium dan auri dengan
G. steyaertanum. Pengamatan hasil inokulasi mempunyai gejala yang sama dengan tanaman akasia yang terserang $G$. steyaertanum.

menginokulasi kedua bibit tersebut dengan 

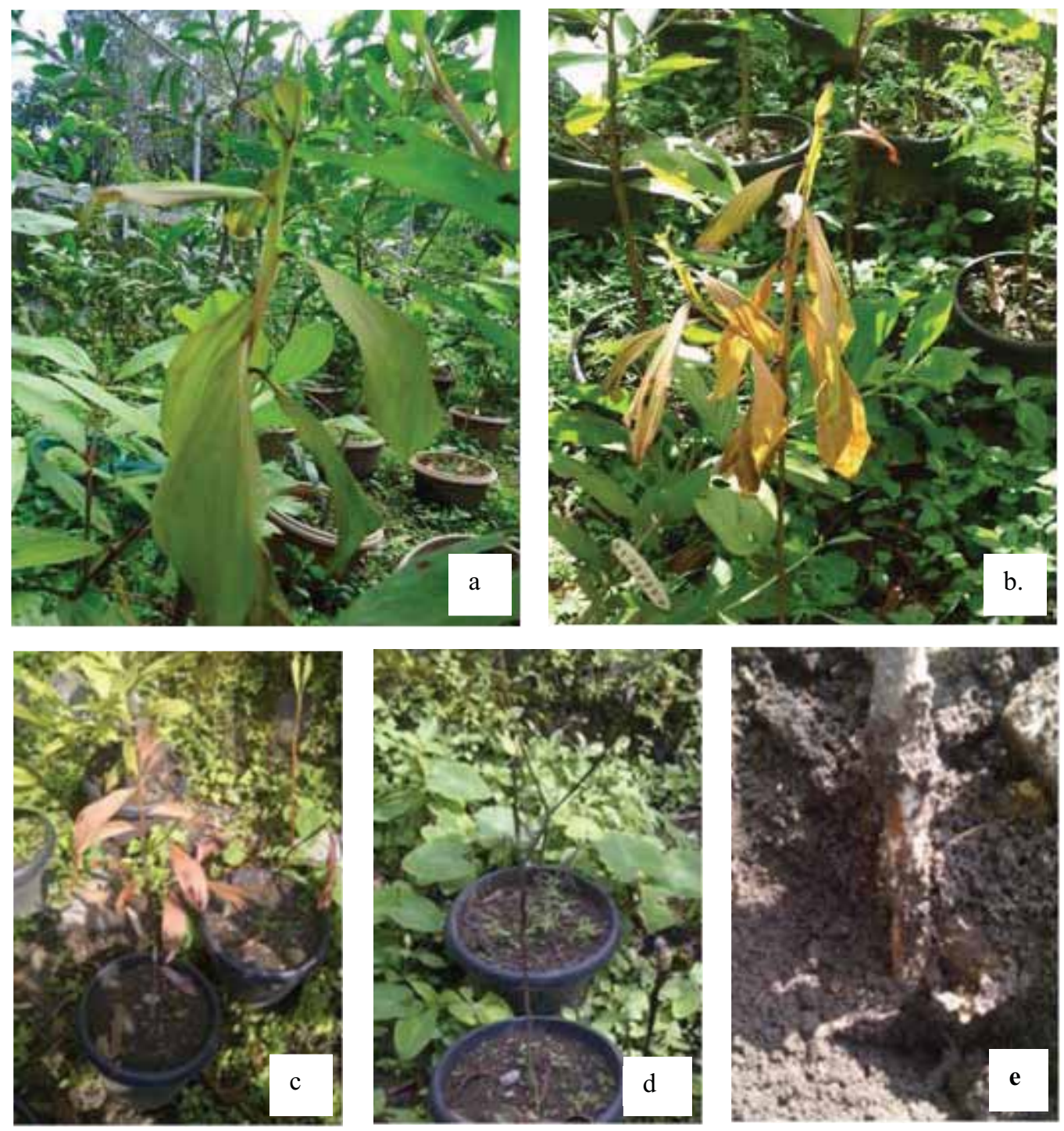

Gambar 8. Mangium yang telah diinokulasi. (a) Tanaman layu; (b) Menguning; (c) Kering; (d) Daun rontok; (e) Akar tanaman yang terinfeksi setelah inokulasi

\section{Tanda-tanda G. steyaertanum di Laboratorium}

Isolat G. steyaertanum diisolasi dari

badan buah jamur $G$. steyaertanum ditumbuhkan pada media PDA (Potato

Dekstrose Agar).

1. Kultur G. steyaertanum menunjukkan miselium berwarna putih pada awal pertumbuhannya (Gambar 9).
2. Pada pertumbuhan lebih lanjut, bagian tengah isolat menjadi berwarna kuning kecoklatan yang pertumbuhannya konsentris mengelilingi pusat (Gambar 10). Struktur miseliumnya cenderung lurus dan halus, cenderung datar dan tidak menggumpal. 

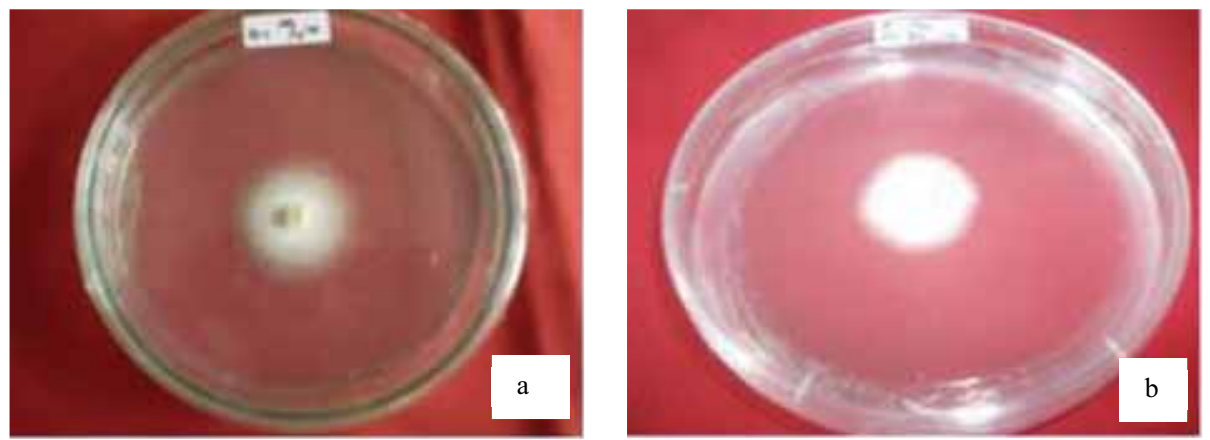

Gambar 9. Isolat G. steyaertanum pada awal pertumbuhan

a. Isolat G. steyaertanum yang menyerang mangium

b. Isolat $G$. steyaertanum yang menyerang auri
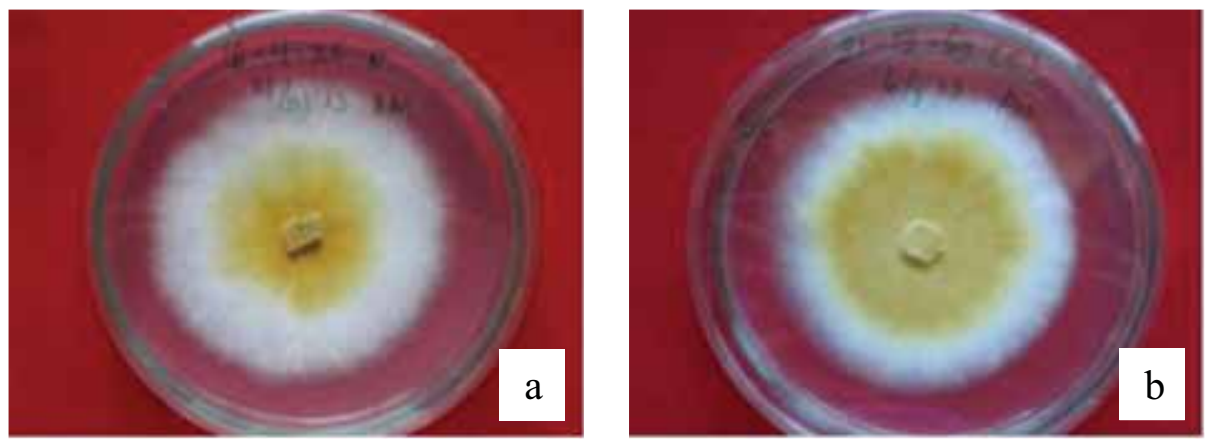

Gambar 10. Isolat G. steyaertanum pada pertumbuhan lanjut

a. Isolat $G$. steyaertanum yang menyerang mangium

b. Isolat $G$. steyaertanum yang menyerang auri

3. Pada pertumbuhan akhir kultur akan berubah warma seluruhnya menjadi kuning-coklat muda hingga tua (Gambar 11). Permukaannya halus dan datar, miseliumnya cenderung menempel pada permukaan media.

Perbedaan isolat G. steyaertanum dan G. philipii dapat dilihat pada Gambar 12a. Miselium awal tampak seperti serabut jelas berwarna putih pekat. Miselium mempunyai serat yang sangat jelas dan tegas, strukturnya bisa dilihat dengan jelas antara miselium satu dengan yang lainnya. Pertumbuhan miseliumnya tidak rapi pada bagian tepinya. Kadang terdapat warna kuning pada bagian tengahnya. Permukaannya terdapat serbuk-serbuk putih yang menyebabkan tampak tidak rata dan tidak halus.

Pada pertumbuhan lanjut akan terbentuk crustose (miselium yang mengeras) berwarna coklat pada bagian tengahnya yang menyebar kearah luar (tepi miselium). Terdapat serbuk putih pada permukaannya. Miseliumnya tetap mempunyai struktur yang tegas dan jelas (Gambar 12b) (Aciar, 2008). Isolat $G$. steyaertanum terkadang juga membentuk crustose seperti G. philipii meskipun stukturnya lebih halus. 

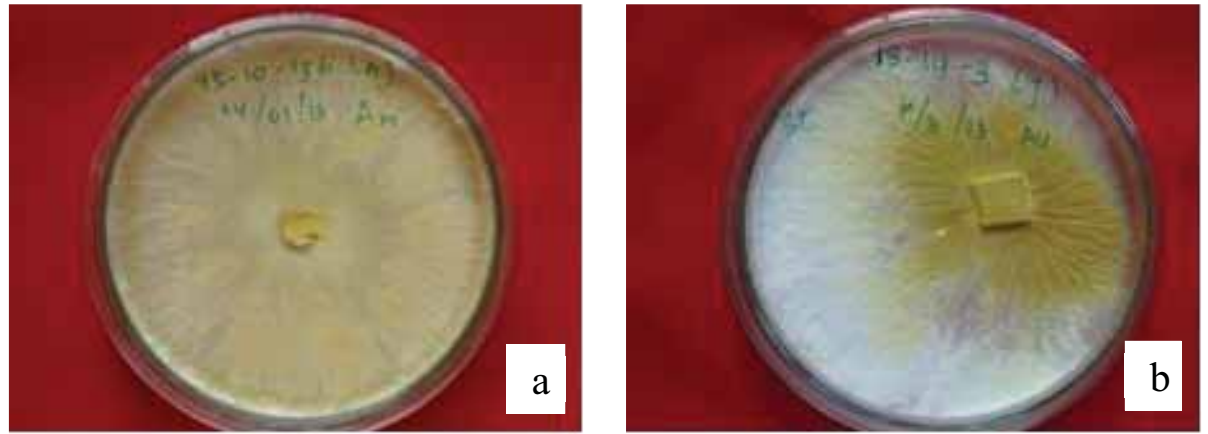

Gambar 11. Isolat G. steyaertanum pada pertumbuhan lanjut

a. Isolat $G$. steyaertanum yang menyerang mangium

b. Isolat $G$. steyaertanum yang menyerang auri

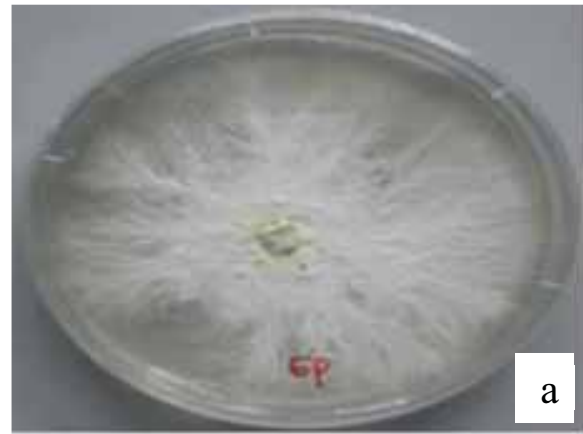

(Dok. Aciar, 2008).

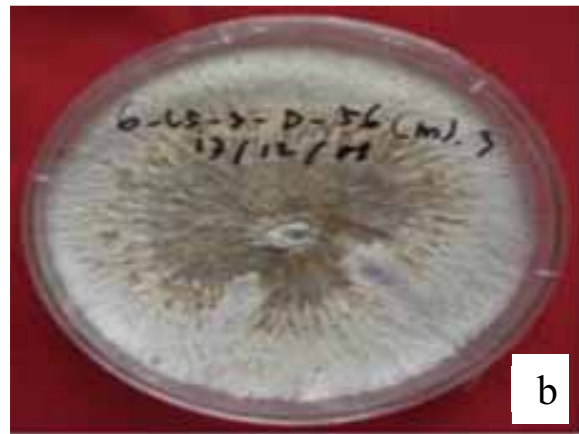

b

Gambar 12. Isolat G. philipii

a. Isolat G. philipii pada pertumbuhan awal

b. Isolat $G$. steyaertanum pada pertumbuhan lanjut

\section{Uji somatik inkompatibilitas $G$. steyaertanum}

Somatik inkompatibilitas dalam basidiomycetes adalah penolakan miselia yang berlainan genetik yang berfungsi untuk menjaga agar dalam suatu individu tidak terjadi perubahan genetik.

Somatik inkompatibilitas mengatur penolakan dan pengakuan alel-alel atau gen-gen yang sesuai dan tidak sesuai yang mengikuti pembentukan sel tubuh dalam sebuah grup organisme. Fries (1987) menjelaskan bahwa studi tentang somatik inkompatibilitas dapat digunakan untuk mengetahui apakah setiap pohon yang terserang jamur berasal dari klon jamur yang sama atau berbeda yang nantinya dapat digunakan untuk menganalisis populasi dan persebaran jamur di lapangan. Studi tentang somatik inkompatibilitas ini dapat digunakan untuk mengetahui distribusi genotip pada suatu populasi (Puspitasari dan Rimbawanto, 2010). Hasil uji somatik inkompatibilitas $G$. steyaertanum, menunjukkan bahwa semua pasangan isolat selain isolat self-pairing menunjukkan reaksi inkompatibel yang berarti terdapat keragaman genetik, genotipnya berbeda dan tidak berasal dari satu klon yang sama, meskipun mempunyai 
kesamaan secara morfologi. Reaksi inkompatibilitas (reaksi ketidakcocokan somatik) ditemukan pada beberapa uji pasangan isolat. Reaksi ditunjukkan dalam berbagai macam fenomena bentuk demarkasi, mulai dari fenomena pembentukan zona jarang antar miselium jamur yang dipasangkan, pembentukan zona bendungan dan pembentukan garis demarkasi yang disertai pembentukan pigmentasi. Bentuk garis demarkasi terbentuk pada hampir semua pasangan isolat yang mempunyai tipe miselia yang berbeda atau tidak identik secara genetik baik pada monosporous atau miselia sekunder (Worall, 1997).
Uji somatik inkompatibilitas $G$. steyaertanum dari KB auri F-1 Wonogiri, mempunyai hasil yang sama dengan uji somatik inkompatibilitas G. steyaertanum dari KB mangium, seperti yang ditunjukkan pada Gambar 14 (Nurrohmah, 2014). Berdasarkan data hasil uji inkompatibilitas somatik $G$. steyaertanum baik yang berasal dari KB mangium maupun dari KB auri, semua pasangan isolat yang berbeda menunjukkan reaksi inkompatibel. Hal ini menunjukkan adanya variasi genetik antara jamur Ganoderma yang menyerang KB mangium dan KB auri.
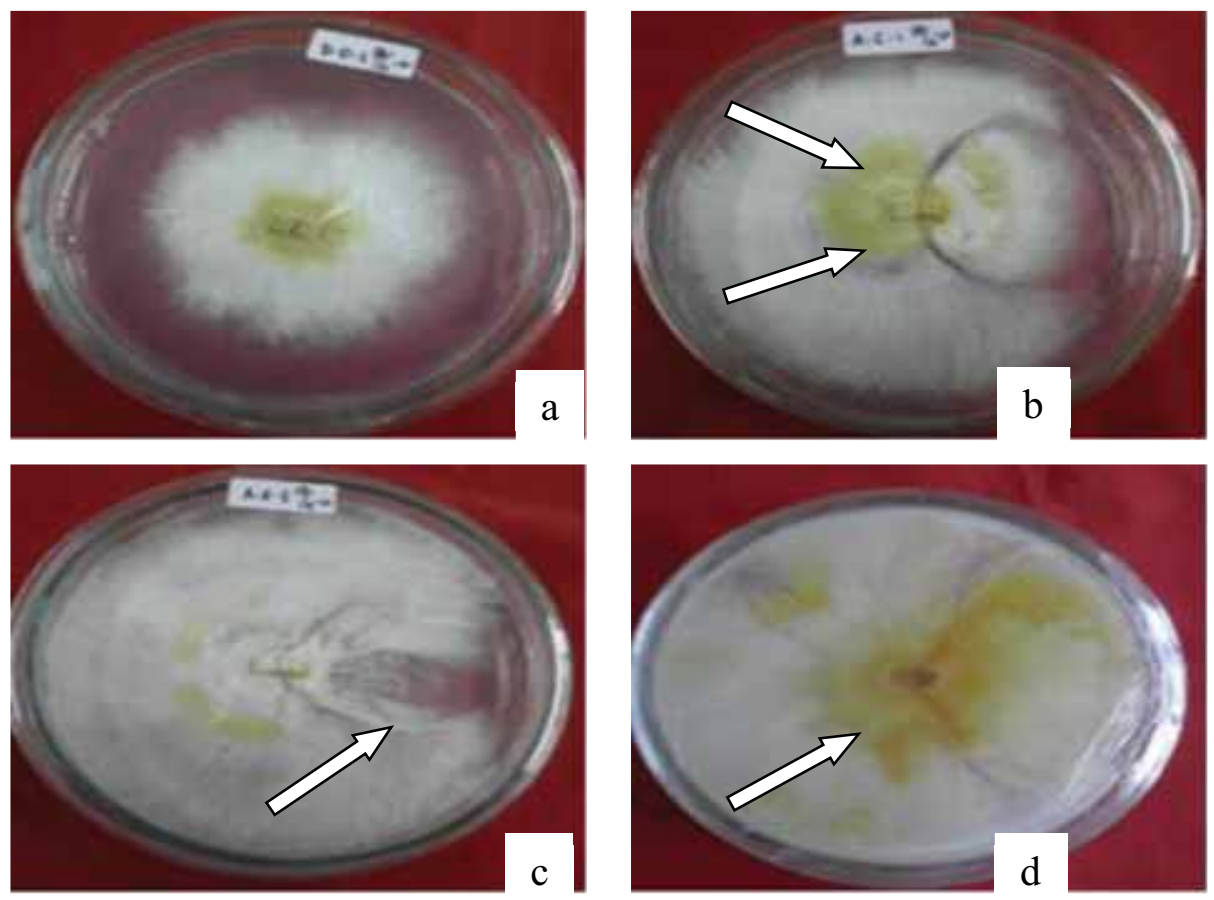

Gambar 13. Uji somatik inkompatibilitas G. steyaertanum dari KB mangium
a. Reaksi kompatibel
b. Reaksi inkompatibel dengan pembentukan zona jarang
c. Reaksi inkompatibel dengan pembentukan zona bendungan
d. Reaksi inkompatibel dengan pembentukan pigmentasi 

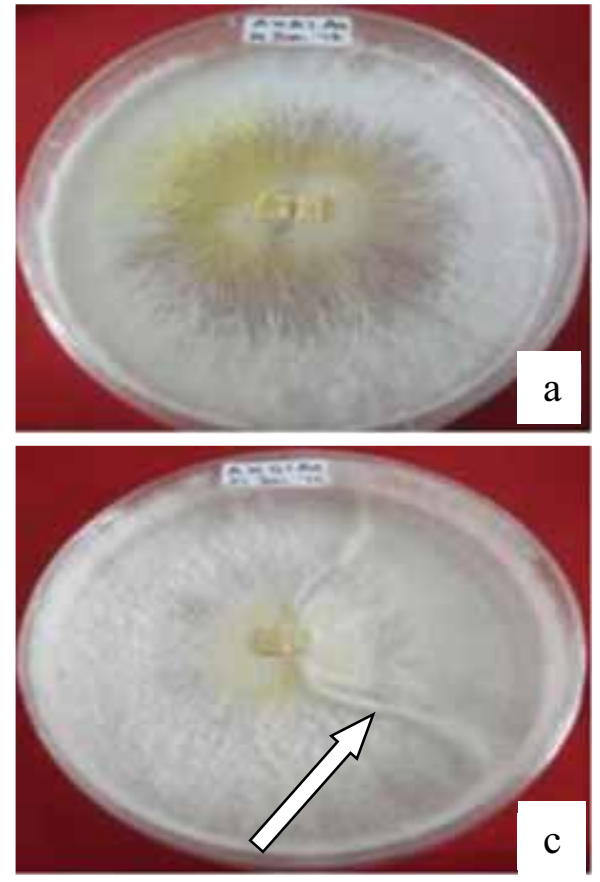

( Doc. Nurrohmah, 2014)
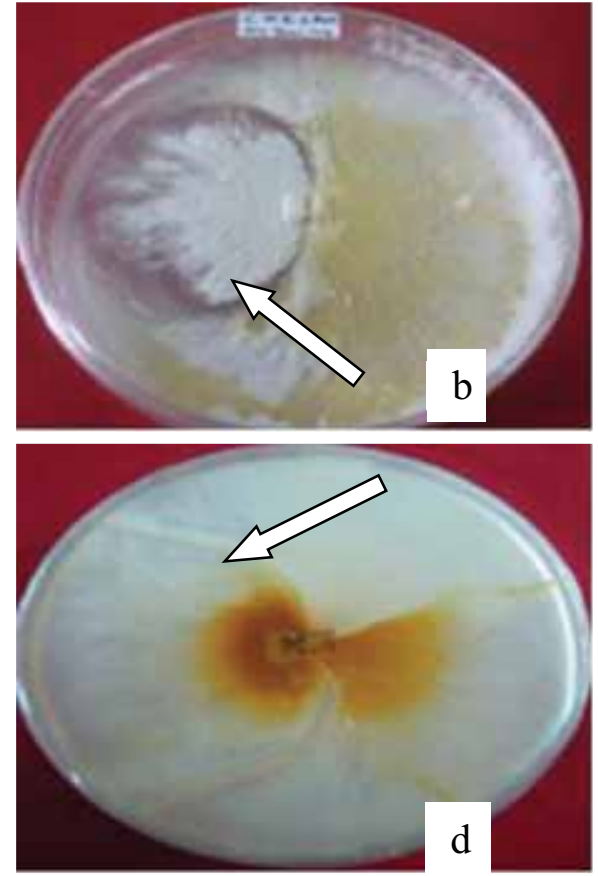

Gambar 14. Uji somatik inkompatibilitas G. steyaertanum dari KB mangium
a. Reaksi kompatibel
b. Reaksi inkompatibel dengan pembentukan zona jarang
c. Reaksi inkompatibel dengan pembentukan zona bendungan
d. Reaksi inkompatibel dengan pembentukan pigmentasi

\section{E. Morfologi G. steyaertanum yang menyerang KB mangium dan KB auri di Wonogiri, Jawa Tengah}

G. steyaertanum termasuk dalam

famili basidiomycetes. Karakterisasi jamur secara konvensional dilakukan melalui pengamatan secara morfologi seperti bentuk dan warna dari badan buah, bentuk dan warna dari miselium dan lain-lain.

Pengamatan karakteristik dari $G$. steyaertanum yang menyerang $\mathrm{KB}$ mangium dan auri di Wonogiri bisa dikelompokkan dalam 3 kelompok yaitu kelompok 1, kelompok 2 dan kelompok 3 (Gambar 15). Badan buah G. steyaertanum tumbuh pada pangkal batang tanaman akasia. Morfologi badan buah $G$. steyaertanum Kelompok 1 menunjukkan pilleus (permukaan) yang bergelombang, berwarna coklat muda sampai coklat tua, mengkilap, badan buah tebal dan ada daerah putih pada daerah tepi pilleus. Morfologi badan buah $G$. steyaertanum kelompok 2 menunjukkan pilleus bergelombang, berwarna cokelat muda sampai coklat tua, tidak terlalu mengkilap, badan buah lebih tipis dari kelompok pertama. Morfologi badan buah G. steyaertanum kelompok 3 menunjukkan pilleus bergelombang, berwarna coklat tua, tidak mengkilap, dan badan buah lebih tipis. Karakteristik badan buah yang sama dari semua grup adalah sessile, stipitate, imbricate dan non imbricate (Shin et al., 1986; Adaskaveg dan Gilbertson, (1988) dalam Seo dan Kirk, 2000). 
Kelompok 1
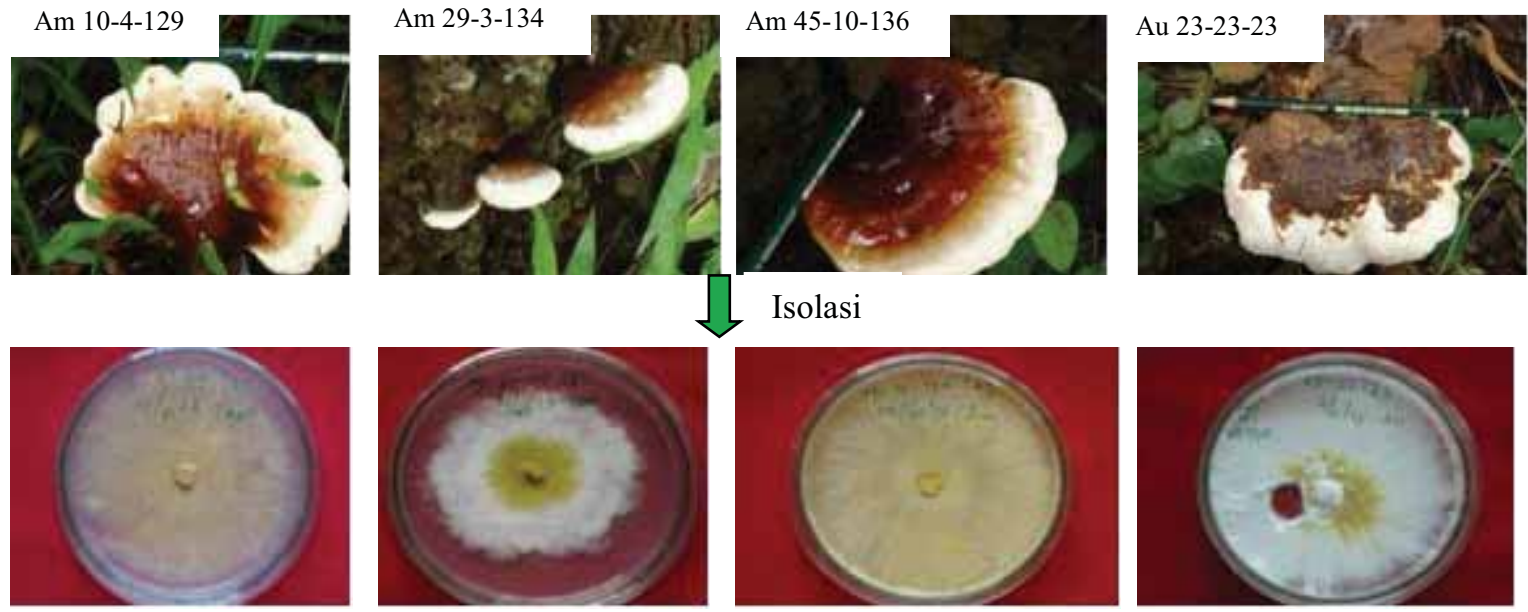

Kelompok 2
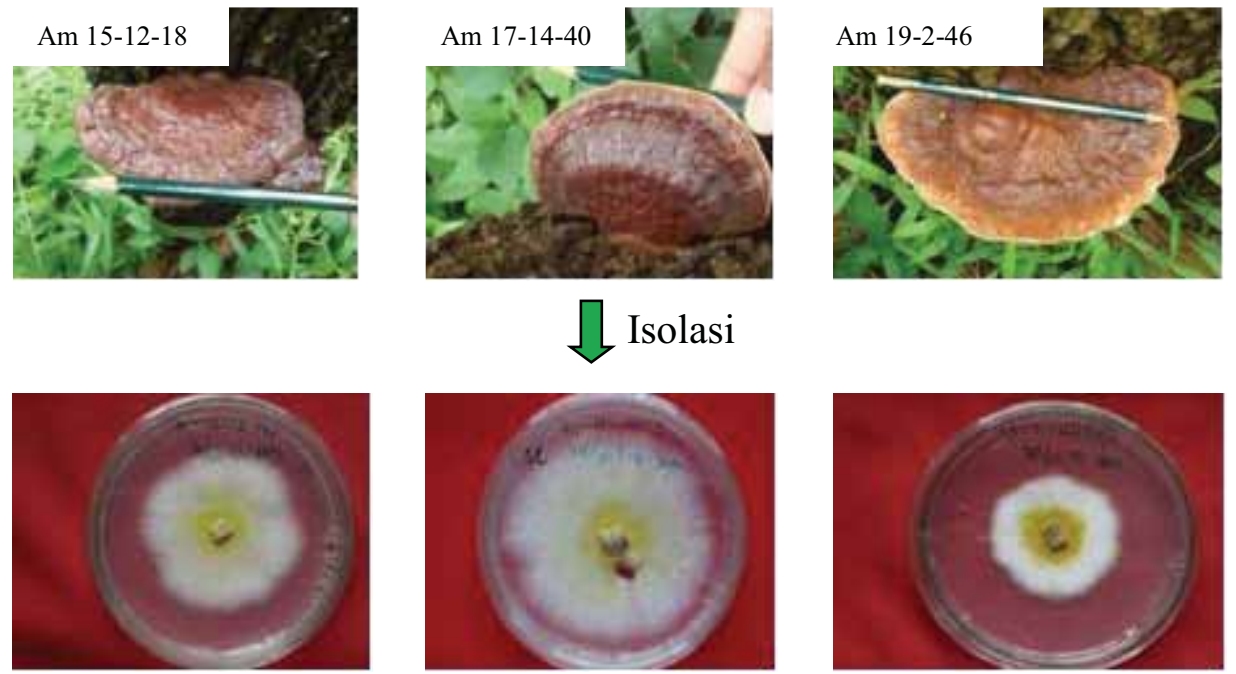

Kelompok 3
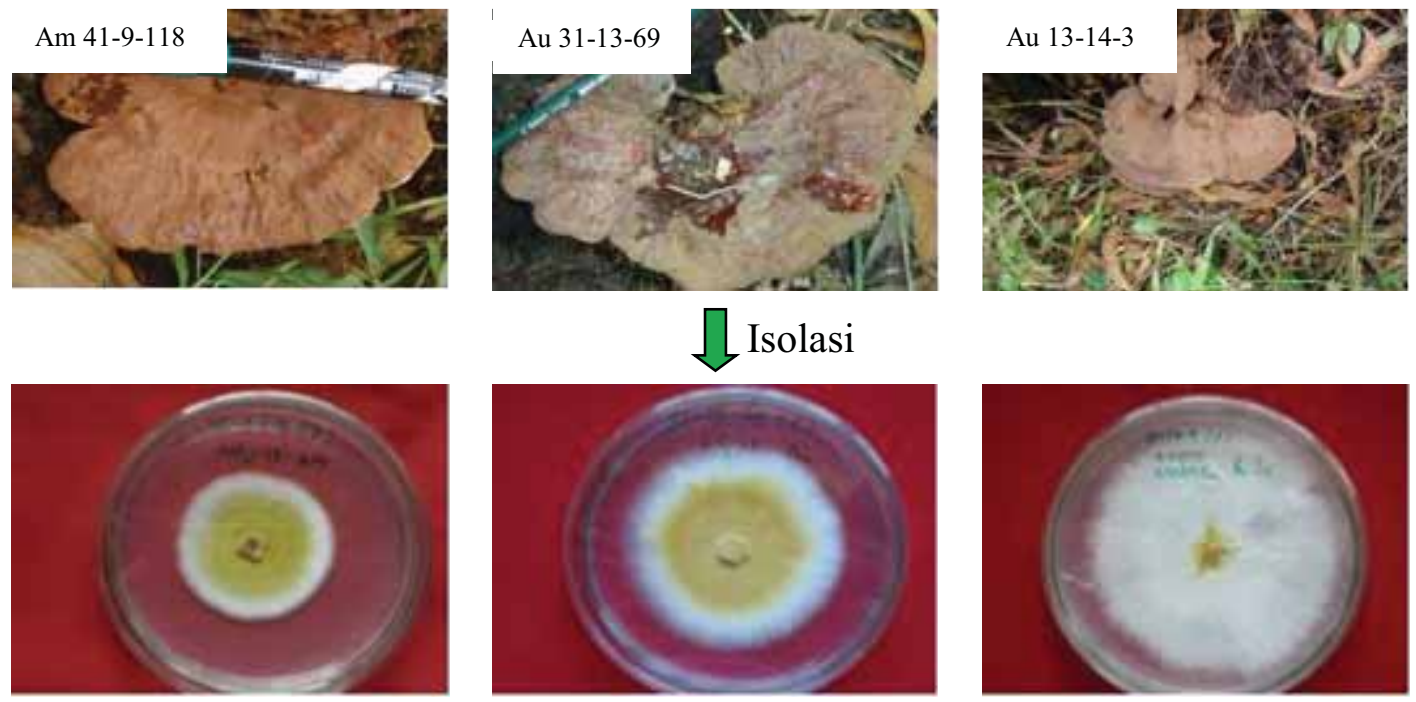

Gambar 15. Pengelompokan karakteristik G. Steyaertanum yang menyerang KB mangium dan auri. 


\section{Daerah hymenophore (bagian}

bawah) pada semua kelompok memiliki karakteristik yang mirip, yaitu berwarna putih. Isolat yang diisolasi dari badan buah, isolat semua kelompok menunjukkan bahwa miselium putih pada pertumbuhan awal dan membentuk daerah kuning gelap pada bagian tengah. Pada pertumbuhan selanjutnya di wilayah ini akan semakin melebar, berubah menjadi cokelat dan membentuk crustose. Jamur yang menyebabkan penyakit busuk akar diklasifikasikan kelas basidiomycetes, ordo polyporales, family polyporaceae. Jamur yang termasuk dalam kelas basidiomycetes memiliki ciri khas yang biasanya tidak terlihat miselium dan badan buah atau umumnya basidiokarp hanya terlihat di permukaan (Hood, 2006).

\section{KESIMPULAN}

Tanaman akasia yang terserang penyakit busuk akar menunjukkan gejala yang sama antara akasia yang terserang G. philipii dan G. steyaertanum. Karakteristik morfologi G. steyaertanum berbeda dengan G. philipii penyebab penyakit busuk akar pada tanaman mangium dan auri.

Hasil pengamatan di lapangan menunjukkan ada 3 kelompok morfologi G. steyaertanum yang berbeda. Diperlukan pengujian lebih lanjut menggunakan analisa DNA untuk mengetahui informasi genetik dari G. steyaertanum.

\section{UCAPAN TERIMA KASIH}

Penelitian ini dilakukan dengan dana DIPA Balai Besar Penelitian Bioteknologi dan pemuliaan Tanaman Hutan Yogyakarta. Penulis mengucapkan terima kasih kepada Tim Akasia atas kerjasamanya dalam penelitian ini dan Tim ACIAR yang sudah banyak membantu dalam pelaksanaan penelitian dan penyediaan referensi dalam penulisan naskah.

\section{DAFTAR PUSTAKA}

Aciar. (2008). Management of fungal root rot in plantation acacias in Indonesia. Final report of laboratory works (tidak dipublikasikan).

Alexopoulus, C.J. \& Mims, C.W. (1979). Introductory Mycology (3rd ed.). New York, Chicester, Brisbane, Toronto: John Wiley and Sons.

Fries, N. (1987). Somatic incompatibility and field distribution of the ectomycorhizal fungus Suillus luteus (Boletaceae). New Phytol, 107, 735-739.

Glen, M., Neale, L. B., Anthony, A. F., Susan, Q. N., Su See Lee, Ragil, I., ... Caroline, L. M. (2009). Ganoderma and Amauroderma species associated with root-rot disease of Acacia mangium plantation trees in Indonesia and Malaysia. Australasian Plant Pathology, 38, 345-356.

Henessy, C., \& Daly A. (2007). Ganoderma Diseases. Darwin: Northern Territory Government, Plant Pathology, Diagnostic Services.

Hidayati, N. (2013). Uji Resistensi Busuk Akar. In Arif N. Populasi pemuliaan untuk jenis unggulan kayu pulp. Laporan Hasil Penelitian, Balai Besar penelitian Bioteknologi dan Penelitian Tanaman Hutan. Badan Litbang Kehutanan. (tidak dipublikasikan). Yogyakarta. 
Hood, I. A. (2006). Mikologi Basidiomycetes. Lokakarya Busuk Hati dan Busuk Akar pada Hutan Tanaman Akasia 7-9 Februari 2006 (pp 34-35). Yogyakarta.

Latifah, Z., \& Ho, Y. W. (2005). Morphological Characteristics and Somatic Incompatibility of Ganoderma from Infected Oil Palm from Three Inland Estates. Malaysian Journal of Microbiology, 1(2), 46-52.

Mohammed, C. L., Barry, K. M., \& Irianto, R. S. B. (2006). Busuk Hati dan Busuk Akar pada Acacia mangium: Identifikasi Gejala dan Penilaian Terhadap Tingkat Serangan. Aciar Proceedings No. 124. Heart Rot and Root Rot in Tropical Acacia Plantations. Yogyakarta, Indonesia.

Nurrohmah, S. H. \& Hidayati, N. (2014). Uji Inkompatibilitas Somatik dan Pertumbuhan jamur Ganoderma dari Kebun Benih Generasi Pertama Acacia auriculiformis di Wonogiri, Jawa Tengah (dalam proses publikasi).

Old, K. M., Lee, S. S., Sharma, J. K., \& Yuan, Z.Q. (2000). A manual of disease of tropical Acacias in Australia, South-East Asia and India. Jakarta: Centre for International Forestry Research.

Puspitasari, D., \& A. Rimbawanto. (2010). Uji Somatik Inkompatibilitas Ganoderma philippii untuk Mengetahui Pola Penyakit Busuk Akar pada Tanaman Acacia mangium. Jurnal Pemuliaan Tanaman Hutan, 4(1), 49-58.

Semangun, H. (2000). Penyakit - Penyakit Tanaman Perkebunan di Indonesia. Yogyakarta: Gadjah Mada University Press.

Seo, G. S., \& Kirk, P. M. (Eds.). (2000). Ganodermataceae: Nomenclature and Classification. Ganoderma Disease of Perenial Crops (pp 3-22). UK: CABI.

Widyastuti S. M, Sumardi \& Hidayati N. (1998). Kemampuan Trichoderma spp. untuk pengendalian jamur akar putih pada Acacia mangium secara in vitro. Buletin Kehutanan, 3, 15-22.

Worall, J. J. (1997). Somatic incompatibility in Basidiomycetes. Mycologia, 89(1), 24-36. 